\title{
THE RELATION BETWEEN FINANCIAL KNOWLEDGE AND ECONOMIC DECISIONS
}

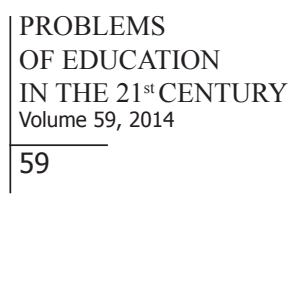

\author{
Sabina Kołodziej \\ Kozminski University, Warsaw, Poland \\ E-mail: skolodziej@alk.edu.pl
}

\begin{abstract}
Nowadays policymakers, government agencies and educators in Poland and in many European countries emphasize the role of individual possibilities to take independent decisions regarding one's financial resources. Consequently, the increased interest in financial education programs is observed. Moreover, the complexity of financial products further demonstrates the need for a financial knowledge when making decisions in this sphere. However, simultaneously, the common observation of numerous examples of irrelevant decision-making, consequently leading to financial (e.g. abundant debt) or professional (e.g. loss of work) problems as well as results of studies on the level of financial knowledge show that in many cases our society, most probably, does not have the indispensable level of analyzed knowledge. The article presents results of 2 studies on the relation between financial knowledge and economic decisions made by Polish young adults. The study 1 focuses on the correlation between financial knowledge and saving decisions while the study 2 financial knowledge and respondents debts. In both studies the level of financial knowledge was measured by the test relating to the current economic situation of Poland, knowledge of basic economic and financial concepts and understanding of basic market mechanisms. Specially designed questionnaires analyzed respondents'savings (study 1) and debts (study 2) decisions. The results of those studies show that examined a group of Polish young adults has an average level of financial knowledge. Moreover, the first study found positive correlation (on the level of statistical trend) between financial knowledge and savings decisions. The results of study 2 showed the higher financial knowledge among people who took credits or loans from bank in comparison with people who take credit and loans outside the banking system. Results obtained in the studies reinforce the idea of the important role of financial education in preparing young people to make their own economic decisions.
\end{abstract}

Key words: debt, financial education, financial knowledge, saving, young people.

\section{Introduction}

Among many consequences of conducted political transformation and introduction the free economy market in Poland and other countries from post - communist bloc is a change in conditions and possibilities of taking economic decisions by individuals. Simultaneously, those changes forced people to acquire knowledge about the market mechanisms and the ongoing financial crisis realized them that the lack of knowledge of the rules governing the world of finance can negatively affect their economic situation. In current conditions units have plenty of available alternatives as well as greater freedom of choice regarding economic behaviors in the sphere of money management, purchasing and professional decisions. However, the common observation of numerous examples of irrelevant decision-making, consequently leading to financial (e.g. abundant debt) or professional (e.g. loss of work) problems shows that in many cases our society most probably does not have indispensable resources for effective behavior on the free market.

A factor that significantly affects one's ability to deal with the surrounding reality and make effective decisions is the level of financial knowledge. Persons who are able to assess their financial abilities in the context of current economic realities, probably will not be prone to overconsumption by taking next credits and loans, because they are aware of money cost 
PROBLEMS

OF EDUCATION

IN THE $21^{\text {st }}$ CENTURY

Volume 59, 2014

60

(Chen \& Volpe, 1998; Huston, 2010). By analogy, acquaintance of mechanisms connected with investing money on the financial market could prevent some of the Polish entrepreneurs and investors from risky decisions, which during recent economic crisis led to the collapse of companies dynamically operating so far, as well as for the loss of many private investors' capital. The lecture of interviews conducted in daily and professional newspapers with persons responsible for these decisions, often indicated that they did not have sufficient knowledge about principles of purchased financial instruments functioning.

The term financial knowledge is often used interchangeably with the notion of financial literacy and is defined as a basic knowledge of key financial concepts (Atkinson \& Messy, 2012). However, Huston (2010) indicated that the differentiation among the constructs of financial literacy, knowledge and education ought to be implemented. General literacy refers to one's ability to write and read (Zarcadoolas, Pleasant \& Greer, 2006), but this term is often defined broadly as the ability to understand and use materials related to prose, document or quantitative information. Analogically, the term financial literacy can be conceptualized as having two dimensions: understanding (which refers to personal financial knowledge) and use (a personal finance application). In this context, financial literacy implies that the person must have the ability and confidence to use his personal financial knowledge to make financial decisions (Huston, 2010). Consequently, the measurement of financial literacy requires not only tests identifying the level of knowledge, but also methods to examine the possibility of its use in specific situation.

According to the above distinction, the majority of previous studies conducted in Poland refers to the level of financial, or even more broadly - economic, knowledge. This research shows that the knowledge in the scope of economy is fragmentary and mainly refers to information publicized in mass media (e.g. inflation, rates of the tax return) or directly related to the respondents (e.g. statutory working week). Moreover, the internal cohesion of this knowledge is very low, so respondents know only some facts, but do not notice the interrelation between particular macroeconomic indicators (Maison, 2013). Moreover, almost 50\% of respondents in 2009 claimed that economic knowledge is not necessary and not useful in everyday life, what shows relatively low and insufficient awareness among society about sense of economic education in common life (Skiba, 2009).

Despite these results, clearly indicating the absence of appropriate educational activities for preparing young Poles to make independent and effective financial decisions, economic education is not perceived by society and the government as important part of Polish educational system. In Poland, there is no National Financial Education Strategy, works on designing such strategy last from 2012 (Grifoni \& Messy, 2012). Financial education programs are developed and conducted by some public institutions (the most intense the central bank - the National Bank of Poland, the stock exchange, the financial supervision authority), private companies from the financial sector (mainly banks) or several nongovernment organizations. The majority of those programs are local (only few are nationwide) and mainly addressed to pupils and students.

The results of studies conducted in countries that have implemented national financial education programs show that education is an important factor influencing the economic decisions and behavior (Ferreira et al., 2012). Moreover, people who are financially educated not only cope better with everyday economic decisions, but also fulfill their civic duties, expressed for example in paying taxes (Kirchler, 2009). In this context many authors emphasize that low level of financial knowledge may adversely affect the economic condition of citizens. It should be noted that effective educational programs should be associated with lifelong learning, and thus not only implemented during compulsory schooling, but also addressed to adults.

The importance of this postulate is further reinforced by the changing demographic situation in Poland and other European countries, resulted in the problem of individual protection in the context of retirement security. These processes resulted in an increase of the importance of training saving habits among young people. Regularly conducted surveys for a long time 
pointed the unsatisfactory level of savings among Poles and Europeans (Potocki, 2013). The majority of Poles has deposits but their value is one of the lowest in Europe. An average Pole has saved 2,8 thousand Euro. This is two times less than the Czech, five times less than the Irishman and nine times less than the Belgian. Moreover, half of the deposits belongs to only 6 percent of the richest Poles, which additionally lowers the assets of the average Pole.

On the other hand, national and international experience shows that a growing group of consumers is affected by the situation of excessive debt. This situation means that the liabilities exceed the income of the consumer. The unstable situation on the labor market and the economic crisis caused that many borrowers found themselves in the group exposed on this risk. In 2001, the European Commission identified excessive household debt as one of the main problems that must be solved. Lack of sufficient economic knowledge was pointed as one of the causes of excessive debt (Adamska, 2008). It should be noted that financial education is not a substitute for consumer protection, but a key element of the consumer protection framework. The lack of consumer education is not the underlying cause for the crisis but it may have contributed to worsening the impact of the financial crisis in Europe in the autumn of 2008 (The financial crisis and financial education, 2009).

\section{Problem of Research}

In the light of these findings, the issue of the relationship between the level of financial knowledge and specific economic decisions regarding personal finances seemed to be important. The existing literature postulates that financial knowledge is an essential element of acquiring ability to cope in the world economy. However, studies rarely examine the above correlation in societies which have a lower level of discussing knowledge, often not allowing the understanding of the principles of the micro and macro economy. Consequently, the research focuses on decisions aimed at ensuring the financial well-being (e.g. savings, investments), which is associated with high levels of financial knowledge, while people with low financial knowledge rather struggling with economic difficulties, manifesting, for example, in the excessive debt.

\section{Research Focus}

The aim of the study was to analyze the relationship between the level of financial knowledge and economic decisions. In particular, the results tended to verify the following hypotheses:

H1. There is a positive relation between financial knowledge and saving decisions among young people.

According to the results of previous research, people with higher level of financial knowledge have more positive attitudes toward savings and declare savings habits (Mandell \& Schmid Klein, 2009).

$\mathrm{H} 2$. The level of financial knowledge is different among respondents who take different type of financial liabilities.

In today's economic reality, the majority of young people is forced to take mortgage to purchase a first flat. These credits are contracted in banks, after a careful check of the property and the creditworthiness of the customer. However, at the same time, the growing trend of over-indebtedness of young people who incurred further financial obligations for the purpose of excessive consumption can be observed. These types of loans are usually taken out at different financial institutions (not just banks) and are often associated with high risk which is not communicated by the borrower. Therefore, this hypothesis assumed that the level of financial knowledge is associated with the type of financial institution in which respondents incur their liabilities: people who take loans and credits in banks have a higher level of financial knowledge compared to those who are borrowing money in para-banking institutions. 
PROBLEMS

OF EDUCATION

IN THE $21^{\text {st }}$ CENTURY

Volume 59, 2014

62

\section{Methodology of Study}

\section{General Background of Research}

At the time of the ongoing economic crisis, saving issues are raised by politicians, educators, and the media as particularly important and treated as a desirable activity. The first study aims to demonstrate the level of financial knowledge among young Poles, characterize their savings activity and analyze the hypothetical relationship between these variables.

In the second study an attempt to answer the question about the relationship of financial knowledge and the tendency to borrow money was made. The background of the research was an assumption that the ability to correctly estimate one's own financial capacity when deciding about credit or loan is very important and it is connected with the level of financial knowledge which allows for a realistic estimation of one's financial possibilities.

It should be noted that the majority of previous studies on the level of financial knowledge, as well as economic decisions, was carried out among students, participating or not in the courses in economics (Huston, 2010). For this reason, their cognitive value is limited because the majority of students does not earn money and remain totally dependent on their parents, so that their economic autonomy is limited. In the referred studies, participants were also young people, but not the students (as seen in the level of education of respondents). For this reason, the difficulty of reaching the subjects was significantly higher, but the results may be more similar to the actual distribution of the variables tested in the population of young Poles. However, the study was conducted as a pilotage, preparing for in-depth research on a large, representative sample.

\section{Sample of Research}

The first study was conducted on a sample of 50 adult young Poles, of whom $48 \%$ were women. Mean age of respondents was 23.75 years. More than half $(57 \%)$ of them graduated from university, while the others had completed secondary education. All respondents were professionally active, major part of them identified his/ her earnings as average (between 350 and 800 Euro). Due to the fact that in this study young people, who begin their earning for a living, were tested, more than half (55\%) declared that they were financially supported by their parents.

The sample of the second study consisted of 61 people, where 27 of them were men. Mean age was 33.66 years, so they were a bit older than the previous respondents. Again, the relatively largest group were people with higher education (75.4\%), followed by the secondary education (19.7\%). Only one respondent was unemployed while others worked mainly in private enterprises $(78.7 \%)$. Participants in the study also declared their monthly earnings. As in the first study, the most popular range of earnings (48.30\%) was between 350 and 800 Euro. However, earnings above this range were declared by $36.70 \%$, which may be associated with a higher average age of respondents.

\section{Instrument and Procedures}

The studies were conducted using a questionnaire divided into two parts. In the first study, one part of the questionnaire contained questions about savings, including savings attitudes and behaviors, regularity of savings, the percentage of income that respondents devote to savings. Sample question: "How often do you save money? a) I save money from each paycheck b) I save money not from each paycheck, but at least every 2-3 months, c) I save money occasionally, at least every three months". The first part of the questionnaire in the second study was devoted to indebtedness and contained questions concerning types of respondent's debts, borrowing motives, forms of financial obligations, as well as estimation of their riskiness. Sam- 
ple question: "Where is your outstanding loan / credit? a) banks, b) in the workplace; c) other financial institutions - non-bank lenders; c) private individuals (friends, family, neighbors)."

In the second part of the questionnaire respondents in both studies filled in the financial knowledge test which contained three types of questions. The first part concerned the issues related to the current economic situation of Poland (such as the rate of inflation or economic growth), the second part of the test examined the knowledge of basic economic and financial concepts (e.g. tax, unemployment) and the third part - understanding of basic relationships and mechanisms of the market (e.g. law of supply and demand). Sample question of the third part of the test: "When a quantity of good on the market increases, its price falls". Respondents task was to choose the true/ false answer.

\section{Data Analysis}

Analysis of data obtained in studies aimed at empirical verification of formulated hypotheses. The Shapiro - Wilk test let conclude that the data distribution is close to a normal distribution, which allowed the use of parametric tests. With respect to the hypothesis 1 , concerning the relationship between the variables, the r-Pearson's correlation was measured, while in case of hypotheses 2 , speaking about the differences between groups, the ANOVA analysis was used.

\section{Results of Study}

The analysis of the answers given by the respondents in the part concerning saving decisions, shows that the vast majority of respondents $(75 \%)$ declared saving of money. Although the remaining $25 \%$ did not save money, they believed that saving is important. The most frequent reasons of not saving money were too low wages and lack of willpower.

Almost half of respondents $(47 \%)$ declared that they saved part of the money from each paycheck. Another large group - 43\% saved money every 2-3 months, and only 10\% of respondents put away some funds less frequently than every three months. Exactly half of the respondents said that they spent on savings between 10 and $25 \%$ of their income each time. More than $26 \%$ of the respondents dedicated on saving more than a quarter of their income. The smallest part of respondents, $23.3 \%$ declared that save less than $10 \%$ of their income .

Regarding the approach to their own budget management, the vast majority (nearly 84 $\%$ ) of respondents claimed the attitude favoring savings. They defined themselves as person who moderately plans his/ her expenses but sometimes buys on impulse. $13 \%$ of respondents describe themselves as people who precisely plan all expenses, try to have the control of their money and defined themselves as a very cost-effective. The vast minority, only $3 \%$ of this group, claimed to be completely impulsive in buying and therefore have problems with savings.

The questionnaire had also questions regarding saving goals and methods of storing money. Results showed that young Poles usually saved for holidays and unforeseen circumstances. Much less frequently appeared objectives such as a house (flat) or a car. When it comes to forms of savings storage mostly Poles chose current account.

The second part of used questionnaire concerned the economic knowledge of respondents. According to the results it can be concluded that the group has an average level of economic knowledge (mean 24.27 on 33 points possible). However, it should be noted that the most difficult questions for respondents were related to the understanding of the economic rights relations, which may indicate the existing difficulties in this field.

In order to verify the first hypothesis which assumed the positive correlation between financial knowledge and propensity to save money the statistical analysis was conducted which table 1 showed. As it can be seen, the correlation between two variables in the study was positive but insignificant. 
Sabina KOŁODZIEJ. The Relation between Financial Knowledge and Economic Decisions

PROBLEMS

OF EDUCATION

IN THE $21^{\text {st }}$ CENTURY

Volume 59, 2014

Table 1. R-Pearson correlation between financial knowledge and saving decisions.

\begin{tabular}{lll}
\hline & & Savings behavior \\
\hline \multirow{3}{*}{ Financial literacy } & r-Pearson & $\mathbf{0 . 2 7}$ \\
\cline { 2 - 3 } & Significance & 0.08 \\
\cline { 2 - 3 } & $\mathrm{N}$ & 50 \\
\hline
\end{tabular}

The analysis of the answers given by the respondents in the second study indicated that exactly half of them have loans or other financial liabilities. Almost half of respondents (46\%) took out their credit and loans in the bank, a fifth in the workplace, while others - in equal number of 10 - in the non-bank institutions or among family and friends. The most common motives $(39 \%)$ for borrowing money among respondents was connected with current needs which cannot be realized with their own money, e.g. renovation, holiday trip. In the second place $(26 \%)$ the respondents marked the credits or mortgage related to the purchase of durable goods (e.g. flat, house, car), which have a very high price, and therefore it is not possible to realize these purchases only with their own money and savings. Respondents also pointed out borrowing money for investment purpose (21\%). It should be noted, that the term "investment" was understood broadly - both as starting their own business, as well as further education (e.g. post-graduate studies).

The questionnaire also included a question about the assessment of riskiness of particular forms of loans or credits. The table below shows the average scores estimated by the respondents on a 7-point scale, where 1 meant no risk, and 7 - very high level of risk.

Table 2. The level of risk of different forms of loans and credits.

\begin{tabular}{llllllll}
\hline $\begin{array}{l}\text { Type of finan- } \\
\text { cial liability }\end{array}$ & Overdraft & $\begin{array}{l}\text { Credit } \\
\text { card }\end{array}$ & $\begin{array}{l}\text { Para-bank } \\
\text { loan }\end{array}$ & $\begin{array}{l}\text { Loan from } \\
\text { family/ friends }\end{array}$ & Mortgage & $\begin{array}{l}\text { Student } \\
\text { loan }\end{array}$ & $\begin{array}{l}\text { Several } \\
\text { loans at the } \\
\text { same time }\end{array}$ \\
\hline Level of risk & 3.53 & 6.51 & 2.74 & 3.28 & 5.79 & 4.64 & 5.06 \\
\hline
\end{tabular}

As it can be seen above, respondents attributed the highest, almost the maximum, level of risk to credit within the credit card account. Next in terms of riskiness is a mortgage and then the situation in which a person has several credits or loans at the same time. According to respondents, the average level of risk is associated with student loan and overdraft in the current account. The lowest level of risk was assigned to loans from friends and family, as well as loans from non-banking financial institutions.

Comparison of the results obtained in the part of the questionnaire devoted to the level of financial knowledge, showed that respondents in second study were characterized by a slightly lower level of financial knowledge and gained a mean score of 19.02 on 33 points possible.

In order to verify the hypothesis assuming the differences between respondents who varied regarding their level of financial knowledge and the type of financial liabilities taken by them, the ANOVA analysis was performed and presented in Table 3.

Table 3. Variance analysis results.

\begin{tabular}{llclll}
\hline ANOVA & Sum of squares & df & $\begin{array}{l}\text { Mean } \\
\text { squares }\end{array}$ & F & Significance level \\
\hline Financial knowledge & 131.38 & 3 & 43.79 & 3.53 & 0.02 \\
\hline
\end{tabular}


The ANOVA analysis confirmed the significant differences in the level of financial knowledge among people who take credit and loans from different institutions which confirmed the second hypothesis. According to the Sheffe test of the variable "type of financial liability" - significant differences occurred in the case of people who took credit from bank and people taking the loan outside the banking system $(\mathrm{p}<0.04)$, indicating the higher financial knowledge among people who took credits or loans from bank. On the level of statistical trend $(\mathrm{p}<0.06)$ was the result of the test between respondents who debt in para-banking institutions and private individuals (family, neighbors, friends). Also in this case the clients of para-bank institutions were found to have lower level of financial knowledge.

\section{Discussion}

Research reported in the article referred to the relation between the level of financial knowledge and economic decisions in the sphere of saving and borrowing money. Both studies analyzed the level of financial knowledge in regard to three scales: acquaintance of the current economic indicators and public charges, defining economic notions and terms and understanding rights and economic relations. Results showed that the level of financial knowledge among Polish young adults was average and in particular respondents had difficulties with the answer to questions about the economic relations and rights. At the same time the majority of them declared the importance of saving money in order to achieve the objectives that cannot be bought from the current income.

These results are in line with previous findings, according to which the level of economic (and financial) knowledge of Poles is low and does not allow them to fully understand the world of economics as well as to undertake the best, in a given situation, decision (Maison, 2013). It should be also emphasized, that both groups in the studies consisted of people who in the majority had a higher level of education, so it can be assumed that - consequently - their level of financial knowledge might be also higher that the average for the Polish population.

Despite the fact that respondents received rather low income (one of the reasons for this could be the age of respondents, who began their career), the majority declared a regular savings - at least every 2-3 months. These results complement the analysis of Potocki (2013), showing that despite the positive attitude towards saving, the amount of income may not allow young Poles to collect savings at a satisfactory level.

The first hypothesis assumed a positive relationship between the level of financial knowledge and saving decisions. The analysis revealed the existence of expected correlation, but only at the level of the statistical trend, which does not allow to confirm the hypothesis. The unambiguous confirmation of this hypothesis would require carrying out another research, perhaps on a larger sample of respondents. However, other studies (e.g. Lusardi, 2004) showing the positive relation between financial knowledge and effective economic decisions (regarding savings) reinforce this finding. It was shown on the group of respondents with low level of education as well as financial knowledge and who saved little that offering them financial education resulted in an increase in the total net worth of savings.

The second study investigated the relationship between financial knowledge and decisions regarding financial liabilities. Results of the study showed that half of the respondents have loans or credits but only less than half (46\%) of those financial instruments come from banks. Other sources of money for the respondents were workplaces, non-banking institutions, as well as family and friends. The most common motive for the loan was linked to the desire to buy expensive goods of two types: connected with current needs (renovation, holiday) or housing purposes (buying a flat, house). It can be assumed that large part of those loans are long-term ones, with a high value. In this context, particularly worrying is the fact of relatively low proportion of loans from the banking system, as well as formulated by the respondents high riskiness of these loans - the second in terms of riskiness is according to respondents mortgage. Available economic analyzes suggest that the mortgage is among credits with the 
PROBLEMS

OF EDUCATION

IN THE $21^{\text {st }}$ CENTURY Volume 59, 2014

66

best repayment rate (Ośko, 2013), which is in contradiction with the opinions formulated by the respondents. Equally important in this context seemed the fact that respondents reported the lowest riskiness of loans from non-bank financial institutions while the interest rate as well as provisions of the contract make these loans associated with high risk.

The results of the analysis of variance showed that the level of financial knowledge plays an important role in making decisions about the debt. Respondents with the lowest level of financial knowledge, most often borrowed money from institutions outside the banking system, which was consistent with the hypothesis 2 . These financial decisions and costs associated with them can become, most likely, a serious burden for respondents whose level of income is not high and as a result can lead to insolvency. Similar results were obtained by Lusardi and Tufano (2009) in a study conducted in United States on relation between debt knowledge and both financial experiences and debt loads. Specifically, individuals with lower levels of debt knowledge tended to transact in high-cost manners, incurring higher fees and using high-cost borrowing. The less knowledgeable also report that their debt loads are excessive or that they are unable to judge their debt position.

The above results, as well as the assessment of riskiness of different types of loans clearly indicate the importance of educational activities in the field of financial knowledge aimed at developing attitudes conducive to saving and preventing adverse financial decision-making. This aspect is particularly important in the case of young people who - as already mentioned in most cases are unable to satisfy their needs (especially connected with dwelling) only from current income. Financial education in the field of incurring financial liabilities could have a positive impact on their long-term financial situation.

\section{Conclusions}

Observation of economic realities and the results of the studies indicated that efficient financial decision-making, and effective coping in the world economy requires an adequate amount of knowledge and skills. This problem is especially important in societies that relatively short operate in a free market economy, where a large part of the population failed to fully assimilate its principles and additionally have not been prepared to take economic decisions in the process of formal education. The study shows that such persons are particularly exposed to bad decisions that adversely affect their financial condition. Therefore, the problem of long-term educational activities aimed not only to raise awareness of the financial issues, but also at shaping appropriate behavior relating to the financial sphere is particularly important.

\section{References}

Adamska, B. (2008). Bankructwo gospodarstwa domowego - nowa instytucja w polskiej gospodarce. In: Bankructwa gospodarstw domowych. Ed: B. Świecka. Warsaw: Difin.

Atkinson, A., Messy, F. A. (2012). Measuring the financial literacy. Results of the OECD/ International Network on Financial Education (INFE) Pilot study. OECD Working Papers on Finance, Insurance and Private Pensions, No. 15, OECD Publishing. http://dx.doi.org/10.1787/5k9csfs90fr4en.

Chen, H., Volpe, R. P. (1998). An analysis of personal financial literacy among college students. Financial Services Review, 7 (2), 107-128.

Ferreira, V. R., Lima, I., Coutinho, L., Klimick, C., Padilha, H., Ayoub, N., Gazel, M., Pereira, V. L. (2012). Can we be debiased? How economic psychology can inform financial education programs. Microcosm of Economic Psychology. Proceedings of the IAREP Conference. Wroclaw: Warsaw School of Social Sciences and Humanities, 98-106.

Grifoni, A, Messy, F. (2012). Current status of National Strategies for Financial Education: A comparative analysis and relevant practices. OECD Working Papers on Finance, Insurance and Private Pensions, 16, OECD Publishing. http://dx.doi.org/10.1787/5k9bcwct7xmn-en.

Huston, S. (2010). Measuring financial literacy. The Journal of Consumer Affairs, 44 (2), 296-316.

Kirchler, E. (2009). The economic psychology of tax behavior. Cambridge: University Press. 
Lusardi, A. (2004). Saving and the effectiveness of financial education. PRC Working Paper, No. 14, http://www.dartmouth.edu/ alusardi/Papers/Financial_Education_2004.pdf.

Lusardi, A., Tufano, P. (2009). Debt literacy, financial experiences, and overindebtedness. NBER Working Paper, No. 14808, http://www.nber.org/papers/w14808.pdf?new_window=1.

Mandell, L., Schmid Klein, L. (2009). The impact of financial literacy ēucation on subsequent financial behavior. Journal of Financial Counseling and Planning, 20 (1), 15-24.

Maison, D. (2013). Polak w świecie finansów. Warsaw: PWN.

Ośko, M. (2013). Zadtużeni we franku - czy naprawdę jest im tak źle? Biznes.pl: http://biznes.pl/wiadomosci/analizy/zadluzeni-we-franku-czy-naprawde-jest-im-tak-zle,5581611,news-detal.html.

Potocki, M. (2013). Polak w europejskiej lidze superoszczędnych narodów. Dziennik Gazeta Prawna, 22.

Skiba, J. (2009). Economic and financial education in Polish schools. RBI-OECD International Workshop on Financial Literacy. Warsaw: National Bank of Poland.

The financial crisis and financial education (2009). Second meeting of the expert group on financial education. Brussels: European Commission. http://ec.europa.eu/internal_market/finservices-retail/ docs/capability/financial_crisis_report_en.pdf.

Zarcadoolas, Ch., Pleasant, A. F., Greer, D. S. (2006). Advancing Health Literacy: A framework for understanding and action. San Francisco: Jossey-Bass.

Advised by Laima Railiené, University of Šiauliai, Lithuania

Received: January 30, 2014

Accepted: March 26, 2014

Sabina Kołodziej

PhD, Assistant Professor, Kozminski University, 57/59 Jagiellonska Street, 03-301 Warsaw, Poland.

E-mail: skolodziej@alk.edu.pl 